This is an electronic reprint of the original article. This reprint may differ from the original in pagination and typographic detail.

Author(s): Nivalainen, Markku

Title: On Thinking the Tragic with Adorno

Year: $\quad 2016$

Version:

Please cite the original version:

Nivalainen, M. (2016). On Thinking the Tragic with Adorno. European Legacy: Toward New Paradigms, 21(7), 644-663. https://doi.org/10.1080/10848770.2016.1200276

All material supplied via JYX is protected by copyright and other intellectual property rights, and duplication or sale of all or part of any of the repository collections is not permitted, except that material may be duplicated by you for your research use or educational purposes in electronic or print form. You must obtain permission for any other use. Electronic or print copies may not be offered, whether for sale or otherwise to anyone who is not an authorised user. 


\section{On Thinking the Tragic with Adorno}

Markku Nivalainen $^{*}$

\section{$\underline{\text { Abstract }}$}

This article seeks to provide a template for understanding the tragic dimension of Theodor W. Adorno's philosophy through a reading of his early collaborative work with Max Horkheimer, the Dialectic of Enlightenment (1944). While Adorno's view has often been considered to be tragic, little has been done to reconstruct the tragic dimension of his thought. I argue that the view of the human condition, presented in the Dialectic of Enlightenment, is founded on metaphysical, epistemological, and ethical convictions that have structural similarities with the positions held by theorists and philosophers of tragedy and the tragic. Since traces of these tragic elements can be found throughout Adorno's mature philosophy, the approach presented in this article may serve as a model for a more detailed mapping and examination of the tragic dimension of his thought in future research.

\footnotetext{
${ }^{*}$ Department of Social Sciences and Philosophy, P.O. Box 35, FI-40014 University of Jyväskylä, Finland. Email: markku.nivalainen@jyu.fi.
} 
Although his view of the human condition is composed in an unmistakably tragic key, Theodor Adorno never wrote an explicit theory of tragedy or of the aesthetic genre of tragedy. ${ }^{1}$ Throughout his oeuvre one finds critical remarks on issues related to tragic works of art and philosophical views on issues that bear similarities to the ways they have been dealt with in both tragedies and the vast secondary literature on the tragic. ${ }^{2}$ The latter rings especially true in the case of his early collaborative work, the Dialectic of Enlightenment (with Horkheimer), which sets the scene for Adorno's subsequent inquiries into the nature of modernity and the human condition.

Adorno and Horkheimer's view of the human condition can be considered tragic along metaphysical, epistemological, and ethical planes. First, the world we inhabit is horrifying in its hostility, a conceit seemingly beyond our control. This leads us to seek power and influence through domination, rendering traditional means of accruing knowledge corrupt as far as they only serve this purpose, which ultimately turns against humanity. There are no transcendental meanings, thereby putting us in a position where we have to fashion our moral and ethical conduct with little hope of understanding this predicament in terms that are not understood as domination. Without recourse to a concealed meaning, we are left with a bleak depiction of a world that is neither fully comprehensible to human agency nor under its control. ${ }^{3}$ This kind of world is not only something human beings act upon but also one that acts upon them, thereby rendering it unaccommodating to our rational and moral ambitions. ${ }^{4}$ In Horkheimer and Adorno's narrative the world is beset with fear causing humans to seek subjectivity accessed through the domination of others. This has overturned human progress while displacing the main source of suffering from nature to society, thereby leaving us with the ethical responsibility to organize social relations in an effort to prevent the re-emergence of barbarism.

In what follows, I will apply a tragic reading of Dialectic of Enlightenment, which will serve as a template for a similar reading of Adorno's mature philosophy. ${ }^{5}$ The article's three subsections are structured around the themes of fear, knowledge, and morality, which are analyzed in light of existing theories of tragedy, some of which may have influenced Adorno. The third subsection 
includes an analysis of Adorno's reading of Hamlet, which is his most sympathetic philosophical analysis of a tragic work of art. ${ }^{6}$ I will conclude with a brief summary of Adorno's scattered remarks on tragedy and the tragic, especially those found in his Aesthetic Theory, while echoing the tragic reading of the Dialectic of Enlightenment laid out in the preceding sections.

\section{Fear, Subjectivity, and Reason}

Horkheimer and Adorno begin their book by presenting a genealogy of modern reason from the perspective of a troubled relationship with nature. ${ }^{7}$ This essentially hubristic relationship has all the elements of tragedy, insofar as humanity is unable to understand nature other than as an object of domination, aims only to gain knowledge that aids in its control and domestication, and therefore prevents the formation of ethically sustainable relationships between human beings with nature and one another. ${ }^{8}$ This narrative provides the grounds for Adorno's tragic view of humanity and culture - the human condition as determined by social forces. This view persists in all of Adorno's subsequent elaborations on culture and morality and is therefore worth exploring at length. The Dialectic of Enlightenment's argument could be summarized thus: Human beings seeks to curb their fear of nature by attempting to control it, initially with magic and ultimately with science. These attempts fail as science reverts into myth, and external nature, subjected to control and domination, is extended to overlap with human nature.

The authors argue that myth is already enlightenment, insofar as it is an attempt to control nature, even when it is done in an unsystematic and non-rational way, such as through the utilization of ritual magic. ${ }^{9}$ In Homeric poetry, myths are systematized into a mythology, forming a primeval form of enlightenment, which is then transformed into the first systematic and comprehensive formalization of the principles of reason in Plato. According to this view, philosophy is about power and control and is defined as having a privative relation to literature, which for Plato meant tragic poetry. ${ }^{10}$ This signature, characteristic of Platonic philosophy, can be seen in Horkheimer and Adorno's Dialectic of Enlightenment as the fear of a murky, undivided 
entity worshipped as the principle of mana in the earliest known stages of western civilization. "Primal and undifferentiated, it is everything unknown and alien; it is that which transcends the bounds of experience, the part of things which is more than their immediately perceived existence" (10). This means that the move from magic to philosophy signifies an attempt to replace the intuitions of the particular with the principles of the universal as the source and guarantor of knowledge. ${ }^{11}$ As a consequence, philosophy can be seen as an attempt to colonize the principle of mana in order to curb the primeval fear that keeps humanity from fulfilling its emancipatory potential: "The doubling of nature into appearance and essence, effect and force, made possible by myth no less than by science, springs from human fear, the expression of which becomes its explanation" (11).

The juxtaposition of myth and science is crucial to Horkheimer and Adorno's argument, according to which enlightenment is not simply a modern ideological construction that seeks to justify the superiority of the natural sciences in the process of eradicating myths. Instead, it is a complex process of control and domination that, paradoxically, also has a liberating effect and seems to be the only means we have for surpassing our animal nature. Only through enlightenment were people able to move from tribal and rural communities to the rationally organized democratic polis. Yet this emancipatory program is not as thoroughly rational as it seems to be, since the attempt to eradicate primal fear is never completely successful. In fact, enlightenment is blind to or neglectful of the fear around which it constitutes itself, and the attempts to overcome fear solely through rational means inadvertently radicalizes it. Against the erratic "outside," reason posits unity in an attempt to force everything into an all-encompassing rational system deduced from the subject: "Nothing is allowed to remain outside, since the mere idea of the 'outside' is the real source of fear" (11). Such a system accepts no ambiguity and seeks total control of the image it creates, which serves as its justification. In other words, the primary function of science is ideological: "Through their claim to universal validity, the philosophical concepts with which Plato and Aristotle represented the world elevated the conditions, which those concepts justified to the status 
of true reality" (16). Thus Philosophy, the first science, is in its formal instantiation the science of the polis, that is, moral and political philosophy. The key themes of Athenian philosophy deal with the ways we should live our lives and organize our societies while inadvertently trying to justify the existing order by utilizing the concepts originating from "the marketplace of Athens." ${ }^{\prime 2}$ As Adorno writes much later in Aesthetic Theory:

Social struggles and the relations of classes are imprinted in the structure of art works; by contrast, the political positions deliberately adopted by artworks are epiphenomena and usually impinge on the elaboration of works and thus, ultimately, on their social truth content. Political opinions count for little. It is possible to argue over how much Attic tragedy, including those by Euripides, took part in the violent social conflicts of the epoch; however, the basic tendency of tragic form, in contrast to its mythical subjects, the dissolution of the spell of fate and the birth of subjectivity, bears witness as much to social emancipation from feudal familial ties as, in the collision between mythical law and subjectivity, to the antagonism between fateful domination and a humanity awakening to maturity. That this antagonism, as well as the historicophilosophical tendency, became an apriori of form rather than being treated simply as thematic material, endowed tragedy with its social substantiality: Society appears in it all the more authentically the less it is the intended object. $^{13}$

The complex relationship between literature and philosophy, morality and politics, the personal and the social, and ideology and experience are themes penetrating both philosophy and tragedy. They are both forms of discourse that strive to enable Athenian citizens to come to terms with the newly developed democratic form of urban living; the demands it sets on the organization of life around the rules and laws that enable and uphold the state; and the persistent failure of reason in enabling human beings to fulfill their moral ambitions. ${ }^{14}$ 
In Dialectic of Enlightenment, the criticism of reason and the attacks on the Platonic attempt to subject people to rational control of each other and of themselves is often presented as a criticism of myth. ${ }^{15}$ A good example is the famous reading of The Odyssey, which for Horkheimer and Adorno tells the story of how Odysseus secularized the primeval world by measuring it out (38). ${ }^{16}$ According to their reading, the way Odysseus resists the temptation of the Sirens by having his body bound to the mast while retaining the ability to listen to their song, effectively allows him to control nature by controlling the natural in him, by violently suppressing his animal nature.

Odysseus's act both violates his own nature and establishes his domination over his fellowmen in a process that has been neatly summarized by Paul Connerton: "He must forcibly restrain his instinctual drives (he is bound to the mast); and he must face obedience upon those who travel with him (they must row), which in turn is only possible because he deludes them (he plugs their ears). $" 17$

For Horkheimer and Adorno, The Odyssey depicts the founding act of the bourgeois self. This paradigmatic modern subject denies its natural grounds in order to gain autonomy. Yet its knowledge remains limited, because the process of instrumentalization that allows the repression of nature requires reason to lose its self-awareness in order to become "hard enough to shatter myths" (2). The loss of self-awareness leads to the denial of our dependence on nature and, as a result, our inability to recognize and understand our instinctual animal drives. ${ }^{18}$ Without taking these aspects of our being into account, all our attempts to control our lives are bound to fail. This launches the kind of trajectory illustrated by the fates of tragic protagonists from Oedipus to Lear.

Horkheimer and Adorno want to remind us that while we like to think of ourselves as rational and autonomous individuals, human nature is much more complex, even horrific. Subjectivity is only gained through an essentially violent act of repression. Before Odysseus sacrifices his true nature in order to gain bourgeois subjectivity, he is more akin to the complex protagonists of tragedies than the essentially rational beings completely in control of their choices and destinies presupposed by enlightened systems of thought. ${ }^{19}$ As an autonomous and heroic 
individual cunningly overcoming the forces of nature, Odysseus becomes the beau idéal of an enlightened subject. As the harbinger of a rational order, he stands on the threshold between the world of myth and the world of the polis, a transitionary period the anxieties of which the Attic tragedies illustrate. The tragic protagonists inhabit a seemingly rationally organized society, but they constantly fail in their attempt to organize their own actions through the same means that enabled that social organization to come about. On an individual level, the type of instrumental reason Plato relied on in his search for emancipatory potential was not enough to deliver humans from the power of those evils that prevented them from attaining the good life.

As the classicist Jean-Pierre Vernant reminds us, the tragic protagonist is no longer an idealized model, unlike the mythical characters that occasionally appear in tragedies, but a problem. ${ }^{20}$ This problem is debated by the chorus, comprised of amateur actors, who dramaturgically and theatrically represent the citizens of the polis. ${ }^{21}$ According to Vernant, the conflict between the individual and the community, the citizen and the polis, is echoed in the very juxtaposition of the chorus and the tragic protagonist. The former is "an anonymous and collective being whose role is to express, through its fears, hopes, and judgments, the feelings of the spectators who make up the civic community," and it is opposed by "the individualized figure whose action forms the center of the drama and who is seen as a hero from another age, always more or less alien to the ordinary condition of a citizen." 22 As individualized as the protagonist is, he is always bound to his community in a number of ways and it would be hubristic to think otherwise. ${ }^{23}$

For a philosopher of the tragic, this has two important consequences. On the one hand, it represents the individual's surrender to the rule of law, thereby legitimizing the rationally oriented organization of the polis. ${ }^{24}$ The civic order of the polis is, after all, a rational construct. ${ }^{25}$ Its purpose is to provide citizens with a framework for acting responsibly, thereby surpassing the mythological order of the gods, whose unpredictability echoes that of an allegedly hostile nature. ${ }^{26}$ As such, thought becomes the tool of control and domination of both nature and people. Nature effectively comes to mean everything excluded from the realm of the polis, and human beings become citizens 
once they are subjected to abstract rules and norms, implemented from without. ${ }^{27}$ On the other hand, the emerging role of tragedy in Athenian society put the inherent contradictions of the polis on public display. ${ }^{28}$ Since this was done through artistic means, it inspired later thinkers to see the polis as a singular unity of aesthetics, politics, and morality. ${ }^{29}$ As J. M. Bernstein has noted, in modernity these concepts are seen as three distinct domains and as result of this strict separation, art has lost its social and political relevance. ${ }^{30}$ Several attempts have been made to counteract this aesthetic alienation by recouping art's sociological significance. Some of these ventures failed to gain the required momentum, as was the case with Richard Wagner's ambitious Gesamtkunstwerk, while others have turned out to be monstrous, such as the fascist aestheticizing of politics. ${ }^{31}$

Yet the need and aspiration of reclaiming the social function of art lives on in the aesthetic criticism of modernity, to which tradition Adorno clearly belongs. In art, Horkheimer and Adorno argue, the whole appears in the particular (14). The work of art thus reveals to us an image of society with its conflicting interrelations of power, thereby bringing within our reach the disconnected limitations reason imposes on our being. This idea, first outlined in the Dialectic of Enlightenment, becomes even more evident in Adorno's later work. Throughout his writing Adorno retains the hope that art can expose the inherent contradictions of modern culture. Whether this could ever help to liberate us from the repressive confines of the dialectic of enlightenment is unclear, but it is certainly an essential part of the process. This hope seems to have far-reaching implications not only for art and aesthetic theory but can also be applied to Adorno's understanding of the "good life." In order to address the moral dimension of Adorno's thought, however, we need to first understand what the curious interplay of art and reason can reveal about our ability to gain knowledge of and mastery over our lives. Insofar as the true nature of our humanity is denied by the very reason we have accepted, on a cultural level, as the sole means for its assessment, we need to find a new way of thinking, that can transcend reason. This position is tragic in a very basic sense: the theoretical attempts to understand our predicament are always bound to fail since reason is 
implicated in causing it. Additionally, as we have seen, the modern rational subject is defined, like so many tragic heroes, by a lack of self-awareness. ${ }^{32}$

\section{$\underline{\text { Aesthetic Truth }}$}

In terms of social and cultural organization, the transition from the rural world to that of the polis was effectively an attempt to move from a mythical order to an enlightened rational order. And as classicists such as Jean-Pierre Vernant and philosophers such as Andrew Bowie have suggested, on the level of cultural self-understanding this transition was mediated through the theatre. ${ }^{33}$ As Bowie has pointed out, art was the only cultural form that could combine "the affective, the ethical and the cognitive. ${ }^{34}$ In this way tragedy served a civic purpose in the budding Greek polis in which what has since become known as the scientific, the aesthetic, the moral, and the political simultaneously kept each other in dialectical check. As these forms became increasingly institutionalized and the polis secured its role as the accepted mode of social organization, this dynamic interrelationship stagnated and philosophy came to dominate the public discourse. ${ }^{35}$

Plato, the best-known exponent of this new political and ideological order, sought in the Republic to cement the position of philosophy as the only legitimate mode of discourse on social and political issues. ${ }^{36}$ Thus, in the course of his argument, he acknowledges that he is participating in "an ancient quarrel" between poetry and philosophy. ${ }^{37}$ The mere existence of a quarrel implies that the two discourses share the same objective, that is, that the dispute has to do with a conflict between two competing modes of discourse regarding social, political, moral, and aesthetic matters. The presence of mythical figures and tropes in Attic tragedy signifies that it belongs to a phase of transition, or, as Adorno argues, tragedy becomes obsolete once this transition is completed and the polis becomes stable enough to discard the past. ${ }^{38}$ This lays the groundwork for the triumph of enlightenment that has come to dominate the trajectory of western cultural and political formations to the present day. The demise of tragedy is part of a rationalization process, which allows the domain of philosophy to be purged of everything that does not fit into an enlightened conception of 
knowledge. ${ }^{39}$ This rationalization entails the eradication of the concrete through "the determining negation of whatever is directly at hand" and the subsumption of the particular under the universal, "which subdues the abundance of qualities" $(20,6)$.

In the new enlightened order, "the clean separation between science and poetry," equates philosophy with reason and associates tragic poetry with myth $(12-13) .{ }^{40}$ This separation provides a starting point for the entire tradition of philosophy that shows a special interest in the aesthetic. ${ }^{41} \mathrm{I}$ referred to this tradition earlier as that of the aesthetic criticism of modernity, since it values the subversive potential of art against the rationalist and scientific ideology of western culture. Horkheimer and Adorno mention these tendencies with a reference to Schelling, whom they paraphrase as having said "art begins where knowledge leaves humans in the lurch" (14). The role of science is then to explain the unique ability of art to record and communicate. Yet this potential of art is grounded in the type of knowledge bourgeois culture seeks to dismiss as irrational and irrelevant. Thus, whenever some sort of concession regarding the power of reason has been made, more room has been given to religious faith rather than to art. ${ }^{42}$ The power of the aesthetic lies in its ostensible ability to bypass rational conceptualization without setting itself into a privative relationship with reason (14). One of the ways art does this is through ambiguity, that is, by pointing outside the representation of reality, which enlightened reason mistakes for reality itself. Later in his career, Adorno chose to call this projection "identity thinking," and his criticism of it could be seen as an attempt to sublate the division between philosophy and poetry. ${ }^{43}$

Art, which, unlike reason, has no difficulty in dealing with particulars, needs reason for interpreting artworks, while reason needs art to reveal its limitations. ${ }^{44}$ This idea, I think, is central to Adorno's aesthetic theory. ${ }^{45}$ The dynamic of art and reason reiterates the complex relationship of myth and reason presented in the Dialectic of Enlightenment. As we have seen, Horkheimer and Adorno see the separation of myth and reason as misguided, insofar as myths had already served a purpose similar to the one later ascribed to philosophy: "Myth sought to report, to name, to tell of origins — but therefore also to narrate, record, explain. This tendency was reinforced by the 
recording and collecting of myths. From a record, they soon became a teaching” (5). Yet as a means of sociocultural instruction, the collection of myths forms a whole that can be subjected to enlightened rational inquiry. Once their rationalization has been accomplished, in a process that turns myth into a rational account and reason into myth, myths need to justify their role as a teaching tool. ${ }^{46}$ This justification, however, can only be conducted within the domain of reason, using the strategies provided by philosophy. This sets philosophy apart from and against poetry and masks the mythic and poetic qualities of philosophical discourse. The tradition of aesthetic criticism sees this Platonic quarrel as prefiguring the rupture that became constitutive of modernity, namely, the separation of the domains of philosophical inquiry into truth, morality, and the beautiful. ${ }^{47}$

In modernity, the domain of truth becomes almost synonymous with philosophy, making it necessary for all inquiries into truth, morality, and art to be philosophically validated in order to be considered scientific. The problem is that the dominant method of philosophical inquiry sets serious limitations on our capacity to understand our human condition: we are forced to conduct our inquiries by relying on a mode of thought that is fully complicit with the regressive socio-economic system known as capitalism. Since the myth of scientific impartiality dominates the discourses of knowledge and politics, the notion of beauty is associated with subjective taste. Subjective qualities are by definition considered to be beyond the reach of universal categories and therefore beyond rational examination, for science does not recognize particulars. Still, the association of beauty with taste contains at least a grain of truth: since taste is a matter of individual preference, the association inadvertently hints at the presence of the particular in aesthetic experience. ${ }^{48}$ The notion of the particular is pivotal to Adorno's thought. ${ }^{49}$ In fact, one possible way of reformulating the core idea of Adorno's ethics is to consider it as a demand to respect the particular, which the enlightenment has sought to deny or even eradicate. ${ }^{50}$ The category of the aesthetic, with its unique ability to communicate without recourse to the traditional corrupt means of communication, enables the bridging of truth and morality. This moral dimension of Adorno's aesthetic theory conveys another aspect of his affinity with the philosophers of the tragic. Although disagreeing with their 
conclusions, Adorno seems to address some of the problems that troubled Arthur Schopenhauer and Friedrich Nietzsche, two notable philosophers of the tragic. ${ }^{51}$

In this regard, the most important aspect of Schopenhauer's philosophy is the epistemological value he grants to art: "literature objectifies the Idea of humanity," he states, and tragedy is "the pinnacle of literature." ${ }^{, 52}$ As Bowie explains, tragedy depicts situations brought about by "the "excess' of the world" that challenge our forms of knowledge. ${ }^{53}$ Denying the failure of our reason to exhaust reality, we seek to maintain an illusion of true knowledge about and complete mastery of the natural. This illusion causes us to adopt a nihilist world-view and to commit horrific acts that appear as rational and morally unquestionable. This is so because the true object of our actions, available to us as the excess, is not within our conceptual reach and we are therefore constantly at risk of ignoring its existence ${ }^{54}$ For Schopenhauer tragedy, and tragedy alone, is able to reveal the world that lies beyond the level of representation, beyond ideology. This world is a world of perennial suffering, brought about by the metaphysical drive that moves it and is indifferent to our individual desires, the will. Having understood and accepted that suffering is an unavoidable dimension of our existence, we are better off abandoning our attempts to seek solace through futile attempts to make the world meet the subjective needs of the will. Doing away with subjectivity brings forth autonomy and objectivity. This happens in aesthetic experience, making art a condition for knowledge. ${ }^{55}$

Taking his cue from Schopenhauer, the young Nietzsche also saw tragedy as a way to contemplate the grounds of our very existence. He defined these grounds as a quasi-deterministic primal force guiding our actions. ${ }^{56}$ This force resembles the aforementioned principle of mana in that both are horrendous and unbearable when faced as such. According to Nietzsche, one of the functions of the thin veneer of civilization is to keep the force at bay. This inability to embrace the totality of life, by denying its grounds, is a defining feature of our decadent and nihilist modern culture. Nietzsche thought that Greeks saw things differently. They allowed the aesthetic 
contemplation of the Dionysian horror by putting the force on public display in tragedy, thereby affirming life as a whole. ${ }^{57}$

Adorno's formulations of the function of art, the birth of philosophy, and the relationship of the identical and the non-identical clearly contain vestiges of Nietzschean and Schopenhauerian notions of the tragic. Both Schopenhauer and Nietzsche agree that there is something wrong with scientific attempts to uncover the truth about the human predicament. If anything, such attempts prevent us from reaching the truth, only allowing us to pursue a truncated form of existence. This view resembles the aforementioned analysis of The Odyssey presented in the Dialectic of Enlightenment. ${ }^{58}$ While Adorno rejects the Schopenhauerian ideas of the necessity of suffering and individual liberation as well as the Nietzschean attraction to irrationalism and his hope of aesthetic reconciliation, he agrees with both on the ability of art to reveal something essential about ourselves, something modern bourgeois science is unable to grasp. Horkheimer and Adorno share the Schopenhauerian view that the grounds of our being are horrifying and that the primal horror this creates is sublimated through magic and ritual, the modern after-image of which is art. Additionally, they agree with Schopenhauer and Nietzsche that there is more to life than reason can grasp. Finally, they seem to share with Nietzsche, among other things, a belief in the necessity to supplement the enlightened conception of the world with an affirmation of the aesthetic.

Adorno believes, then, that works of art provide valid information about the world around us. ${ }^{59} \mathrm{He}$ argues that they do so by reflecting and reproducing the conditions of the socio-historical processes to which they belong while simultaneously managing to say something that applies to the entire human condition. ${ }^{60}$ Art is mediated by history and society, which burdens the artwork with an internal tension that mirrors the tensions constitutive of modern societies. ${ }^{61}$ Works of art thus communicate an epochal self-consciousness, which communicates the truth about the specific historical situation that affects us all within the sphere of western capitalism. Art can therefore serve a function similar to that which tragedy is believed to have served in and for the polis. This enables the aesthetic to act as a corrective to the one-sidedness of enlightenment rationality, with art serving 
the moral function of reminding us of our duty to live responsibly and to ensure that all avoidable suffering, both human and non-human, is indeed avoidable. But Adorno, unlike his romantic predecessors Wagner and the young Nietzsche, does not advocate a unilateral aesthetic reconciliation of culture. ${ }^{62}$ His negativism insinuates that we should abstain from utopian idealism and instead understand the convergence of the aesthetic and the epistemological as a moral demand in a tragic key. ${ }^{63}$

\section{$\underline{\text { Tragic Morality }}$}

We have seen how the critique of reason and myth presented in the Dialectic of Enlightenment reclaims the aesthetic in critiquing society from a moral standpoint. ${ }^{64}$ While the object of Horkheimer and Adorno's criticism is modernity, their position is complicated by their tracing the history of the dialectic — that functions both as the object and the starting point of the critique -all the way back to the primeval human condition, thereby emphasizing an intricate relationship between past and present. ${ }^{65}$ Modernity is best understood, they argue, as denoting a socio-historical formation in which an attempt to dominate nature and replace the myths of earlier eras has transformed into a myth of its own by enabling the logic of this process of control to permeate every part of life.

The new mythology is that of reason and it appears to replace classical mythology, understood as superstitious and magical, with a scientific one that is ostensibly more open, selfreflexive, and logical. There is no room for complex temporal and power-laden relationships, let alone personal failings, such as those found in the dialectical realm of tragedy. The mythology of reason is based on what Horkheimer has called traditional science, a form of knowledge that "arrives at causal explanation that forms part of a system of universal propositions" on "the basis of empirical observation." ${ }^{\prime 66}$ Through revision and deduction, the universal propositions form an everexpanding network of knowledge that covers all human and natural life. The ideal of deduction is 
the mathematical calculation echoed in modern bourgeois society, which Horkheimer and Adorno consider to be "ruled by equivalence" (4).

Enlightenment makes particular things comparable by reducing them to abstract quantities, since modern scientific rationality does not recognize specific representation: "For the Enlightenment, anything which cannot be resolved into numbers, and ultimately into one, is illusion; modern positivism consigns it to poetry" (4-5). Poetry, which here can stand for art in general, is associated with what is excluded from the domain of proper science. This equates the relationship between science and art with that between mythology and the principle of mana. It also hints at the "peculiar, mysterious, and even dangerous" nature of the aesthetic, which tragedy utilizes by putting societal horrors into public display. ${ }^{67}$ According to this view, life in modernity is fragmented and our traditional theoretical means to understand it—and by extension the world—are essentially limited. To make sense of the wrong life that cannot be lived rightly, we need to supplement our logical reasoning with the aesthetic apprehension of our catastrophic predicament. ${ }^{68}$

Through their theory of reification, Horkheimer and Adorno connect their critique of positivism with Marx's analysis of capitalism. Theirs is an attempt to show the ideological underpinnings of modern science that seeks to present itself as value-free, as abstract and neutral. Marx had argued that exchange requires imposing an imaginary equivalence on materially different objects. ${ }^{69}$ In a society that organizes its economy around exchange, the process in which the particular use-value of things is replaced with a universal exchange value comes to dominate people's consciousness: "Not merely are qualities dissolved in thought, but human beings are forced into real conformity" (9). This leads us to misrepresent things in ways that inadvertently reinforce the existing social order and then take this representation for reality, thereby making relations between human beings similar to those between things. ${ }^{70}$ In other words, the principle of exchange describes everything as identical with everything else, paralleling the way positivism sees everything in terms of the mathematical model. Capitalism and science, exchange and abstraction, are complementary, cementing the ideological organization of society and rendering criticism 
impossible by monopolizing the discourse on truth, as happened in the Athenian polis. Philosophy ends up being complicit in the advancement of capitalist ideology by resigning itself to interpreting the world and inadvertently covering up the tragic nature of reality. Although all the possibilities to realize a rationally organized change for the better have been exhausted, we are still morally obliged to resist this ideology by pointing out its contradictions and excesses. ${ }^{71}$ This can only be done through discourses that resist capitalist appropriation, such as critical philosophy and autonomous art, which complement each other in both revealing the ideological underpinnings of thought and expression. $^{72}$

And this is as far as Adorno believes we can go, for we are no longer capable of articulating positive alternatives for our current condition. According to his negativist view on ethics, we cannot know what the good life entails or how a just society should be organized. The only understanding we can obtain from the right life is by experiencing the wrong one. That is, while we can recognize bad things and feel duty-bound to prevent them from happening, we are unable to define or depict good things. In our current condition, it would make little sense even were we able to define the good things by envisioning alternatives, since the tools we have for their assessment are always already ideologically compromised. In terms of moral philosophy, the problem is how to combine an intuitive aesthetic truth with the corrupt conceptional rationality into a motivating ethical theory. Adorno's solution is, on the one hand, to envision a mode of dialectical thinking that remains aware of the limits of conceptual thought—which are revealed through aesthetic experiences that communicate the non-conceptual--but strives to overcome them. ${ }^{73}$ On the other hand, he presents us with a thoroughly negativist moral view that is summed up by the encouragement to "live less wrongly."74

This is well in line with the tragic view of morality found in classical Athenian drama. There are no--and can never be any--tragic ethical imperatives, because the consequences of actions cannot be fully anticipated. This does not mean that anything is permitted, but that we are responsible beyond our immediate sphere of influence. This is illustrated in a number of tragedies 
through the cycle of violence that turns the sins of fathers, and sometimes grandfathers, into those of the sons. In this way our moral incentive clashes with our inability to make sense of the world and thereby of our own actions. This emphasizes the split between the actor, who has the moral demand imposed upon her, and the world, the context and object of the action. Later in his career, Adorno uses Hamlet, a paradigmatic modern tragedy, to illustrate this predicament in which we are obliged to act but cannot. ${ }^{75}$ As is well known, Hamlet feels obliged to take revenge for the murder of his father by his uncle, but keeps coming up with excuses not to carry out the act. When he eventually does murder his uncle, amid homicidal and suicidal mayhem, he seems to do so in spite of rational thought, not as a consequence of it. ${ }^{76}$ Adorno's analysis of "the Hamlet syndrome" suggest that the rationalization of society separates us from our will, that is, the impulse that allows us to break the cycle of deliberation and enter "the realm of objects" in an act that momentarily reconciles reason and nature. ${ }^{77}$ Since this reconciliation brings death and violence, the play is an excellent metaphor for, to quote Ross Wilson, "the precariousness of a world with the potential either to establish peace and security for all its inhabitants, or to slide at any moment into unimaginable horror." ${ }^{, 78}$ In order to avoid the horror, Adorno formulates the ultimate moral guideline for human beings as a categorical demand "to arrange their thoughts and actions so that Auschwitz will not repeat itself, so that nothing similar will happen." ${ }^{, 79}$ And this has to be done in a way that acknowledges the limitations of reason and thereby of the only critical tools we have at our disposal. It also reminds us of the conceptual shift of modernity which displaced the locus of horror from nature to society.

This brings us back to the theme of the tragedy of enlightenment. As we have seen, Horkheimer and Adorno remind us that the autonomy of strong, enlightened subjects is an illusion, hypostasized as it is on the denial of our ties to nature. Modernity has been ideologically constructed as an abstract ahistorical context that legitimizes the actions, both malevolent and benevolent, of purportedly modern individuals, who are conceived of as their own masters, fully in charge of their own destiny and accountable to no one.$^{80}$ This "enlightened" view obscures the fact 
that our history consists of a series of catastrophes that we have brought about. ${ }^{81}$ Given that according to Adorno, Hamlet reveals the tragic nature of the modern situation, it seems difficult, if not impossible, to think of a way to change the world without inflicting suffering on people and nature. It is unlikely that Adorno would have found the postwar generations, such as ours, as having managed to organize their thoughts and actions according to his moral imperative. ${ }^{82}$

In order to follow Adorno's moral imperative, we need to act in a way that reconciles reason and nature without direct recourse to or eventual regression to violence. This, again, is the kind of conundrum tragedies tend to depict. They present us with a picture of an unjust reality within which actions have unintended consequences, where actors find it difficult, if not impossible, to pursue moral goals without perishing in the attempt. "In tragic drama," Karoline Gritzner writes, "the particular gestures of the individual subject become ethical claims in a universe of contradiction and injustice. ${ }^{\prime 83}$ A central philosophical quality of tragedy is the possibility to tarry with ethical questions without expecting a final ethical solution, which is one of the reasons Plato found tragedies so dangerous. ${ }^{84}$ They show the world, be it social or natural, to be either hostile or indifferent to human aspirations and reveals weaknesses and faults in humans and the reality they inhabit. The persistent theoretical and aesthetic interest in tragedies shows the importance of this peculiar kind of negativism for our attempt to make sense of the human condition. ${ }^{85}$ And as we have seen, Horkheimer and Adorno clearly share this interest with the tragedians.

\section{Adorno on Tragedy}

Horkheimer and Adorno's tragic view of the human condition is a central feature of the Dialectic of Enlightenment. It is therefore somewhat surprising that Adorno never dealt with tragedy or the tragic in a sustained way. The subject nonetheless seems to have preoccupied him at different stages of his writing career, as testified by his numerous remarks scattered throughout his work. The question of tragic art gained special importance in the works of Adorno's fellow Marxists, Georg Lukács and Bertolt Brecht, yet even then Adorno’s criticism remained somewhat opaque and he did 
not consider the possibility and implications of holding a tragic view beyond the realm of the aesthetic. $^{86}$

The most illuminating of Adorno's comments on tragedy and the tragic are found in his Aesthetic Theory. While the comments are critical, they are by no means dismissive. ${ }^{87}$ On the one hand, Attic tragedy is mentioned as the possible origin of the idea of aesthetic autonomy, a notion Adorno held in high esteem. ${ }^{88}$ On the other hand, he finds classical tragedy redundant. Even if it dealt with societal and cultural themes in a critical manner, it was thoroughly embedded in the society and culture that enabled it. ${ }^{89}$ According to Adorno, no form of art has universal validity, and Attic tragedy cannot therefore be squarely transported to our present situation. ${ }^{90}$ Additionally, he believes that the best social criticism art can provide is through works that do not explicitly commit to criticism or to any other cause external to art, a view he repeats in a number of places throughout his work. ${ }^{91}$

In his criticism, Adorno distinguishes between tragedy as a form and the subject matter of particular plays, seeing the relevance of the form as dependent on a work's social truth content. ${ }^{92}$ Notably, the truth content is not dependent on the subject matter of the artwork. This means that the phenomenon of tragic art is constituted in and through a dialectic of its individual elements: the tragic form, the tragic subject matter, and the social truth content. Each one of the elements constitutes a part of its own historical trajectory and is shaped within a specific historical situation from which it cannot be removed without being abstracted and generalized into an ahistorical idea. ${ }^{93}$ In other words, tragedy as a form is no longer possible, even though the tragic content of "evil and death" endures. ${ }^{94}$ The subject matter of classical tragedies can no longer communicate a truth relevant to the modern social situation.

Adorno can therefore be negatively positioned along a line of thinkers who have argued that the tragic is something that can be extrapolated from the ancient tragedies and is therefore separate from them. ${ }^{95}$ While proponents of such a view tend to consider tragedies as having historical value only, insofar as they cannot reveal the truth about modern times, they may still consider the tragic 
as a category that deals with our attitudes to fundamental aspects of the given: death and suffering. These aspects remain crucial to our existence and a critical response to them is vital for our cultural self-understanding if we are to forge a more ethical society from which unnecessary suffering is eradicated. ${ }^{96}$ To quote Adorno:
All that by which aesthetic pedants once zealously distinguished the tragic from the mournful - the affirmation of death, the idea that the infinite glimmers through the demise of the finite, the meaning of suffering - all this now returns to pass judgment on tragedy. Wholly negative artworks now parody the tragic. Rather than being tragic, all art is mournful, especially those works that appear cheerful and harmonious. ${ }^{97}$

Any hint of a hidden meaning beyond the chaos of everyday life risks giving us a false glimmer of hope. ${ }^{98}$ Works of art have to somehow point beyond the level of ideological representation lest they affirm the ideologically constructed status quo. ${ }^{99}$ Since death and suffering are an inevitable part of the human condition, we have every reason to retain a tragic sensibility, which can only be done by understanding the tragic in terms that do not impose upon it a concealed meaning in the sense of redemption or closure. ${ }^{100}$ In order to save the tragic from the limits set to it by a redundant dramatic form, we must find the modern locus of the tragic outside the traditional forms of tragic art. ${ }^{101} \mathrm{I}$ believe Adorno finds this locus in autonomous art and, most importantly, in philosophy. ${ }^{102}$

In conclusion, the analysis of the tragic sense of negative dialectics in relation tragedy as an art form enables us to see Adorno's philosophy as a part of a rich tradition of critical thinking that has sought to bridge the gap between philosophy and literature and has shed light on the rifts that constitute modernity while informing our cultural self-understanding. This tradition helps us understand the political implications of our ethical predicament by exposing the web of relations that forms our subjectivity and distances us from our natural human selves. Since his preoccupation with tragedy and the tragic recurs throughout his mature philosophy, the approach presented in this 
article may serve as a model for a more detailed mapping and examination of the tragic dimension of Adorno's thought. 


\section{Acknowledgments:}

I wish to thank Hanne Appelqvist, Jussi Backman, and Nicola Blunden for their helpful comments on earlier versions of this article.

Funding: I thank the Faculty of Social Sciences of the University of Jyväskylä, Finland, for supporting my research.

\section{$\underline{\text { Notes }}$}

${ }^{1}$ The most sustained readings of Adorno as a philosopher of the tragic have been presented by Samir Gandesha and Karoline Gritzner. See Samir Gandesha, "The Theatre of the 'Other': Adorno, Poststructuralism and the Critique of Identity," Philosophy \& Social Criticism 17.3 (1991): 243-63, and Karoline Gritzner, Adorno and Modern Theatre: The Drama of the Damaged Self in Bond, Rudkin, Barker and Kane (London: Palgrave Macmillan, 2015), 163-81. Instead of Odysseus, Horkheimer and Adorno initially planned to use Sophocles's Oedipus Tyrannous in Dialectic of Enlightenment as an illustration of the birth of modern subjectivity. Vestiges of this reading remain in the text. Gandesha has mapped these in his 'Enlightenment as Tragedy: Reflections on Adorno's Ethics," Thesis Eleven 65.109 (2001): 109-30. In addition, Christopher Rocco has read Horkheimer and Adorno in light of tragedy, arguing that Dialectic of Enlightenment shows how to combine tragic and enlightened modes of thought. See especially chapter 6 of his Tragedy and Enlightenment: Athenian Political Thought and the Dilemmas of Modernity (Berkeley: University of California Press, 1997). Horkheimer's, and by the same token the Frankfurt School's, animosity toward "tragic knowledge" has been analyzed by Christoph Menke. See his "Critical Theory and Tragic Knowledge," in Handbook of Critical Theory, ed. David M. Rasmussen (Oxford: Blackwell, 1999), 57-73.

${ }^{2}$ The distinction between tragedy and the attribute called 'the tragic' is constitutive of our modern understanding of the phenomenon in question. Tragedy is generally considered to refer to both the dramatic form and its individual manifestations, especially in the classical Greek plays, while the tragic signifies a philosophical dimension that is extrapolated from the tragedies and the vast 
theoretical corpus inspired by them. See Vassilis Lambropoulos, The Tragic Idea (London: Bristol Classical Press, 2012), and Julian Young, The Philosophy of Tragedy: From Plato to Žižek (Cambridge: Cambridge University Press, 2013).

${ }^{3}$ The point of Adorno's negative dialectics is to maintain and think through contradictions without any kind of an assumption that they could be overcome. Since Adorno claims that all critique is immanent critique, his view of philosophy reflects his view on modernity, which thereby resembles secularized tragedy. This affects the way we can conceive of human autonomy and agency. For a reading of the Dialectic of Enlightenment in terms of agency, see Martin Shuster, Autonomy after Auschwitz: Adorno, German Idealism, and Modernity (Chicago, IL: University of Chicago Press, 2014). For a reconstruction of Adorno's view of modernity, see Jay M. Bernstein, Adorno:

Disenchantment and Ethics (Cambridge: Cambridge University Press, 2001), 236.

${ }^{4}$ Bernard Williams, Shame and Necessity (Berkeley: University of California Press, 2008), 163-65.

${ }^{5}$ For the sake of convenience, I shall ignore the question of authorship regarding the Dialectic of Enlightenment and treat it as part of Adorno's oeuvre. Themes found in the book are also touched upon in the work of both Horkheimer and Adorno written at the time of Dialectic of Enlightenment's initial publication, making it difficult and in my view pointless to try to trace the origin of any of the views presented in the book to either one of the authors. See Max Horkheimer, Eclipse of Reason (New York: Continuum, 1974), and Theodor W. Adorno, Minima Moralia: Reflections from Damaged Life, trans. Edmund Jephcott (London: Verso, 2004).

${ }^{6}$ Whether Hamlet is a tragedy is an intricate question. Even those who, for whatever reason, think it is not, often choose to discuss it when they discuss tragedies. See, for example, George Steiner, The Death of Tragedy (New York: Hill \& Wang, 1963).

${ }^{7}$ The view can be found incorporated into the thought of many modern thinkers. This is notably the case with Freud, who, together with Nietzsche, was one of Adorno's key influences. See especially chapter 2 of Sigmund Freud, Civilization and its Discontents, trans. David McLintock (London: Penguin, 2004), e-book. 
${ }^{8}$ See Gandesha, "Enlightenment as Tragedy."

${ }^{9}$ Unsystematic and seemingly irrational in the sense that the results of rituals remain unpredictable. Max Horkheimer and Theodor W. Adorno, Dialectic of Enlightenment: Philosophical Fragments, ed. Gunzelin Schmid Noerr, trans. Edmund Jephcott (Stanford, CA: Stanford University Press, 2002), xviii; hereafter cited in the text.

${ }^{10}$ On a related note, Horkheimer and Adorno assert in Dialectic of Enlightenment that the "separation between science and poetry" is echoed in the "separation of sign and image," which philosophy sees as a chasm "between intuition and concept" and has desperately but unsuccessfully tried to bridge. Philosophy, they claim, is "defined by that attempt" $(12,13)$.

${ }^{11}$ In other words, the move from myth to philosophy can be defined as an attempt to replace transcendence (divine authority) with immanence (empirical inquiry). Philippe Lacoue-Labarthe and Jean-Luc Nancy have suggested that this failed to remove the need for authority. For them, myth is essentially about identification, which National Socialism exploited in the attempt to fashion a new national myth for Germany. Philippe Lacoue-Labarthe and Jean-Luc Nancy, "The Nazi Myth,” trans. Brian Holmes, Critical Inquiry 16.2 (1990): 291-312.

${ }^{12}$ Plato's and Aristotle's concepts “originated, as Vico put it, in the marketplace of Athens; they reflected with the same fidelity the laws of physics, the equality of freeborn citizens, and the inferiority of women, children, and slaves" (Dialectic, 16).

${ }^{13}$ Theodor Adorno, Aesthetic Theory, ed. Gretel Adorno and Rolf Tiedemann, trans. Robert HullotKentor (London: Continuum, 2002), 232. One implication is that the social truth content demands the works of art to take a certain type of form. This then is Adorno's main criticism of modern attempts to recreate tragedies: is no longer possible to present tragic content in the form found in Attic tragedy. Inasmuch as the transition from rural communities to the polis and the birth of subjectivity, for example, are a thing of the past, so too is the art form that was born out of a need to tackle these phenomena. Throughout his oeuvre, Adorno makes numerous remarks on tragedy's obsoleteness. A good example is the difference between the notion of subjectivity inherent to 
tragedy and the way subjectivity is actualized under the present conditions as little more than the locus of mere survival: "Tragedy evaporates because the claims of the subjectivity that was to have been tragic are so obviously inconsequential.” Theodor W. Adorno, Notes to Literature, ed. Rolf Tiedemann, trans. Shierry Weber Nicholsen (New York: Columbia University Press, 1992), vol. 2, 252.

${ }^{14}$ See Andrew Bowie, From Romanticism to Critical Theory: The Philosophy of German Literary Theory (London: Routledge, 1997), 176.

${ }^{15}$ This is in part because mythology is as ideologically compromised as science. Both necessitate a split between the human being and the world. Tragedy is forced to deal with this split and the ensuing problematic power-relations. As Horkheimer and Adorno write: “The myths which the tragic dramatists drew on were already marked by the discipline and power which Bacon celebrated as the goal"' (Dialectic, 5).

${ }^{16}$ This is but one aspect of their critique of myth. See Jay M. Bernstein, "Negative Dialectic as Fate. Adorno and Hegel," in The Cambridge Companion to Adorno, ed. Tom Huhn (Cambridge: Cambridge University Press, 2004), 21-30. One should also bear in mind that Horkheimer and Adorno initially planned to illustrate their point with a reading of Oedipus Tyrannous. See Gandesha, "Enlightenment as Tragedy."

${ }^{17}$ Paul Connerton, The Tragedy of Enlightenment: An Essay on the Frankfurt School (Cambridge; Cambridge University Press, 1980), 69.

${ }^{18}$ See Alison Stone, “Adorno, Hegel, and Dialectic," British Journal for the History of Philosophy 22.6 (2014): 1118-41.

${ }^{19}$ Jean-Pierre Vernant and Pierre Vidal-Naquet, Myth and Tragedy in Ancient Greece, trans. Janet Lloyd (New York: Zone Books, 1990), 32:

What is this being that tragedy describes as a deinos, an incomprehensible and baffling monster, both an agent and one acted upon, guilty and innocent, lucid and blind, whose 
industrious mind can dominate the whole of nature yet who is incapable of governing himself? What is the relationship of this man to the actions upon which we see him deliberate on the stage and for which he takes the initiative and responsibility but whose real meaning is beyond him and escapes him so that it is not so much the agent who explains the action but rather the action that, revealing its true significance after the event, recoils upon the agent and discloses what he is and what he has really, unwittingly, done? Finally, what is this man's place in a world that is at once social, natural, divine, and ambiguous, rent by contradictions, in which no rule appears definitely established, one god fights against another, one law against another and in which, even in the course of the play's action, justice itself shifts, twists, and is transformed into its contrary?

${ }^{20}$ Vernant and Vidal-Naquet, Myth and Tragedy in Ancient Greece, 25: "In the new framework of tragic interplay, then, the hero has ceased to be a model. He has become, both for himself and for others, a problem."

${ }^{21}$ Bowie, From Romanticism to Critical Theory, 176.

${ }^{22}$ Vernant and Vidal-Naquet, Myth and Tragedy in Ancient Greece, 24.

${ }^{23}$ Aristotle famously claims in his Poetics that tragedies arouse fear (phobos) and pity (eleos). See Aristotle, Poetics, in Classical Literary Criticism, ed. Dawn A. Russell and Michael Winterbottom, trans. M. E. Hubbard (Oxford: Oxford University Press, 2008), 66. The pity he refers to is a very specific kind of "amorphous fellow-feeling," as Gloria Fisk calls it, which occurs between equals. Paraphrasing Vernant and Vidal-Naquet, she continues that tragedy functioned to remind the citizen-spectators that they are equally susceptible to misfortune, a notion having to do with the special meaning of eleos. Gloria Fisk, "Putting Tragedy to Work for the Polis: The Rhetoric of Pity and Terror, before and after Modernity," New Literary History 39.4 (2008): 893.

${ }^{24}$ Bowie, From Romanticism to Critical Theory, 176: "[Tragedy is] the revelation of the truth that constitutes the forming of the state in which it is performed, the truth that the institution of law inherently entails conflict and suffering in ways which cannot be rationalistically explained away." 
${ }^{25}$ As Fisk points out, the polis is "a creation and manifestation of human logos." Fisk, "Putting Tragedy to Work for the Polis," 894.

${ }^{26}$ Cf. C. Fred Alford, "Responsibility without Freedom: Must Antihumanism Be Inhumane? Some Implications of Greek Tragedy for the Post-Modern Subject," Theory and Society 21.2 (1992): 159.

${ }^{27}$ For example, Andrew Bowie has suggested that the tribunal at the end of Aeschylus's Oresteia represents the rule of law, thereby symbolizing the installation of the order of the polis into an essentially rural community and a transition from myth to reason. Bowie, From Romanticism to Critical Theory, 176. See also Douglas Klusmeyer, “Beyond Tragedy: Hannah Arendt and Hans Morgenthau on Responsibility, Evil and Political Ethics," International Studies Review 11.2 (2009): 346.

${ }^{28}$ Bowie, From Romanticism to Critical Theory, 176: "It does in many ways make sense to see Athenian tragedy, not as a symbolic expression of what that society already was, but as an event in which it revealed to itself what it was and constituted itself as a public sphere."

${ }^{29}$ See Mark Berry, "Richard Wagner and the Politics of Music-Drama," The Historical Journal 47.3 (2004): 666-71.

${ }^{30}$ Jay M. Bernstein, The Fate of Art: Aesthetic Alienation from Kant to Derrida and Adorno (Cambridge: Polity Press, 1992), 1-16.

31 "Aesthetic alienation" is Bernstein's term. As is well known, the German fascist aim to grant aesthetics a role in the constitution of the political and the social included an ideological attempt to appropriate Wagner's revolutionary program as a part of their project. While Wagner's ambitions were both nationalist and socialist in nature, interpreting them as national socialist required violent revision of his ideas. See Berry, "Richard Wagner and the Politics of Music-Drama," 663-83. See also João Pedro Cachopo, “The Case of Wagner Against the Grain: The Disagreement between Nietzsche and Adorno, and Its Relevance Today," Parrhesia 19 (2014): 36-50.

${ }^{32}$ See Gandesha, "Enlightenment as Tragedy."

${ }^{33}$ Bowie, From Romanticism to Critical Theory, 176. 
${ }^{34}$ Andrew Bowie, Aesthetics and Subjectivity: From Kant to Nietzsche (Manchester: Manchester University Press, 2003), 172.

${ }^{35}$ See Vernant and Vidal-Naquet, Myth and Tragedy in Ancient Greece, 23-28.

${ }^{36}$ Plato wanted to banish the poets from the polis, but it is unclear what he actually sought to condemn and for what reason. Throughout the Dialogues, he presents a number of contradictory arguments against the tragedians, all filtered through the ironic character of Socrates, and it is difficult to tell which were his actual views—or whether he even held any. See Young, The Philosophy of Tragedy, 3-20. It should also be noted that the Plato accused of the one-sided rational organization of the city also considered as ideal a state where every citizen shared both the goods and ills of their peers. See Fisk, "Putting Tragedy to Work for the Polis," 893.

${ }^{37}$ Plato, Republic X, 607b, in Complete Works, ed. John M. Cooper and D. S. Hutchinson, trans. George M. A. Grube, rev. C. D. C. Reeve (Indianapolis: Hackett, 1997).

${ }^{38}$ As Adorno writes in Aesthetic Theory, "the pantheon of neutralized culture concealed" the "agon of Greek tragedy" (35).

${ }^{39}$ On the Apollonian "Socratic rationalism," condemned by Nietzsche who promoted the dark Dionysian side of existence, and denied already by the Athenians, see Peter Uwe Hohendahl, The Fleeting Promise of Art: Adorno's Aesthetic Theory Revisited (Ithaca, NY: Cornell University Press, 2013), e-book, chap. 3.

${ }^{40}$ As Stathis Gourgouris writes: "It is fair to say that since Plato's famous decision there has been an implicit but consistent association of the poetic act with a peculiar, mysterious, and even dangerous sort of knowledge.” Stathis Gourgouris, Does Literature Think? Literature as Theory for an Antimythical Era (Stanford, CA: Stanford University Press, 2003), 2

${ }^{41}$ The tradition tends to orient itself against Kant, but as we have seen, the roots of the key arguments regarding the aesthetic can be traced back to Plato. See Chris Thornhill, "Adorno Reading Kant," Studies in Social and Political Thought 12 (2006): 99-100. 
42 "The bourgeois world was rarely amenable to such confidence in art. Where it restricted knowledge, it generally did so to make room for faith, not art" (Dialectic, 14).

${ }^{43}$ The critique of identity thinking is an essential element of Adorno's negative dialectics. His preferred philosophical method, the building of constellations, could be interpreted as a way to acknowledge the separation of the supposed earlier unity into the domains of aesthetics, politics, and morality. See Theodor W. Adorno, Negative Dialectics, trans. E. B. Ashton (New York: Continuum, 1973), 5.

${ }^{44}$ The truth content of art needs "to be brought out by an accompanying philosophical cum social theoretical analysis" that provides art with "the critical discursive tools" it otherwise lacks. Martin Jay, Songs of Experience: Modern American and European Variations on a Universal Theme (Berkeley: University of California Press, 2005), 355.

${ }^{45}$ For more on the topic, see Lambert Zuidervaart, Adorno's Aesthetic Theory: The Redemption of Illusion (Cambridge, MA: MIT Press, 1991), 48-53.

${ }^{46}$ Horkheimer and Adorno: “Art had to demonstrate its usefulness” (Dialectic, 13).

${ }^{47}$ As is well known, Kant fashioned his three critiques along these lines. The strictness of this division for his philosophy, however, is a matter of dispute. See, Bernstein, The Fate of Art, 2. ${ }^{48}$ Cf. Bernstein, The Fate of Art, 2.

${ }^{49}$ According to Gritzner, the prioritizing of particularity is part of Adorno's tragic sensibility: “An awareness of tragedy draws attention, on the one hand, to the fate of particularity in late-capitalist society (the erasure of differences between particular objects and individuals under reified formulas and schemata). On the other hand, the concept of tragedy may also permit us to make hidden social contradictions and antagonisms reappear.” Gritzner, Adorno and Modern Theatre, 167.

${ }^{50}$ Over the past fifteen years, a lot has been written about Adorno's moral philosophy. J. M. Bernstein's exhaustive attempt to uncover the moral program implicit in Adorno's oeuvre pretty much set the parameters for subsequent enquiries. See J. M. Bernstein, Adorno: Disenchantment and Ethics (Cambridge: Cambridge University Press, 2001). For a useful summary, see Nick Smith, 
“Making Adorno's Ethics and Politics Explicit," Social Theory and Practice 29.3 (2003). See also Fabien Freyenhagen, Adorno's Practical Philosophy: Living Less Wrongly (Cambridge: Cambridge University Press, 2013), e-book.

${ }^{51}$ Adorno's debt to Nietzsche is often acknowledged. See Hohendahl, The Fleeting Promise of Art, chap. 3. For a book-length study, see Karin Bauer, Adorno's Nietzschean Narratives: Critiques of Ideology, Readings of Wagner (Albany: State University of New York Press, 1999). On Adorno and Schopenhauer, see Mathijs Peters, Schopenhauer and Adorno on Bodily Suffering: A Comparative Analysis (Houndmills, UK: Palgrave Macmillan, 2014), esp. 166-67 and 199-202.

${ }^{52}$ Arthur Schopenhauer, The World as Will and Representation, trans. and ed. Judith Norman, Alistair Welchman, and Christopher Janaway (Cambridge: Cambridge University Press, 2010), vol. $1,279$.

${ }^{53}$ Andrew Bowie, German Philosophy: A Very Short Introduction (Oxford: Oxford University Press, 2010), 71.

${ }^{54}$ See Peters, Schopenhauer and Adorno on Bodily Suffering, 166-67.

${ }^{55}$ See Dylan Trigg, "Schopenhauer and the Sublime Pleasure of Tragedy," Philosophy and Literature 28.1 (2004): 171-72.

${ }^{56}$ Bowie, Aesthetics and Subjectivity, 282. Nietzsche went on to develop this idea into a theory of the will to power, which was much later adopted by Hans Morgenthau as the grounds for his theory of international relations as a way to come to terms with irreconcilable conflicts. See Robbie Shilliam, "Morgenthau in Context: German Backwardness, German Intellectuals and the Rise and Fall of a Liberal Project," European Journal of International Relations 13.3 (2007): 299-327.

${ }^{57}$ Bowie, Aesthetics and Subjectivity, 281-82. See also Richard Seaford, "Introduction" to Aeschylus, The Oresteia: Agamemnon, Choephoroe, Eumenides, trans. George Thomson (New York: Alfred A. Knopf, 2004), xiii.

${ }^{58}$ It should also be noted that the excess referred to by Schopenhauer, Nietzsche, and Adorno share uncanny similarities. Safranski adds Heidegger to the equation, but omits Schopenhauer: 
‘Nietzsche's 'Dionysus,' Heidegger's ‘Being,' and Adorno and Horkheimer's 'nature' are all designations for the colossal dimensions of existence.” Rüdiger Safranski, Nietzsche: A

Philosophical Biography, trans. Shelley Frisch (London: Granta Books 2003), 345.

${ }^{59}$ This question of the truth content of art is an essential and contested part of Adorno's aesthetic theory. For a book-length assessment of the thesis, see Zuidervaart, Adorno's Aesthetic Theory. Schopenhauer does not think it possible for us to reach truth, but we may form adequate knowledge through aesthetic experience. See Trigg, "Schopenhauer and the Sublime Pleasure of Tragedy," $171-72$.

${ }^{60}$ Adorno famously describes this special ability of artworks by comparing them to monads. For a critical analysis of the artwork's ability to represent reality, see Hohendahl, The Fleeting Promise of Art, chap. 4.

${ }^{61}$ See Adorno, Aesthetic Theory, 4-6.

${ }^{62}$ One way of putting it is to say that Adorno wants to avoid what Jean-Luc Nancy has analyzed as nostalgia for a lost community. He argues that the idea of a past unity that has since been lost is prevalent in western political philosophy. It also tends to include the idea of a level of cultural selfreflection we are no longer capable of: "The lost, or broken, community can be exemplified in all kinds of ways, by all kinds of paradigms: the natural family, the Athenian city, the Roman Republic, the first Christian community, corporations, communes, or brotherhoods--always it is a matter of a lost age in which community was woven of tight, harmonious, and infrangible bonds and in which above all it played back to itself, through its institutions, its rituals, and its symbols, the representation, indeed the living offering, of its own immanent unity, intimacy, and autonomy." Jean-Luc Nancy, The Inoperative Community, trans. Peter Connor, Lisa Garbus, Michael Holland, and Simona Sawhney (Minneapolis: University of Minnesota Press, 1991), 9.

${ }^{63}$ According to Fabien Freyenhagen, Adorno is a methodological, epistemic, and substantive negativist. Freyenhagen, Adorno's Practical Philosophy, introduction. 
${ }^{64}$ J. M. Bernstein has suggested that Arendt, who also grounds her critique on the aesthetic, offers the most plausible theory available for the expansion of Adorno's thought into the realm of the political. See J. M. Bernstein, "Political Modernism: The New Revolution and Civil Disobedience in Arendt and Adorno," in Arendt and Adorno: Political and Philosophical Investigations, ed. Lars Rensmann and Samir Gandesha (Stanford, CA: Stanford University Press 2012), 56-77.

${ }^{65}$ As Hohendahl notes, Adorno does not think that there is "a clear-cut distinction between modern and primitive culture." Hohendahl, The Fleeting Promise of Art, chap. 4. This is a view that can also be found in Nietzsche: “To Nietzsche, 'modern man' in The Birth of Tragedy is not affiliated mainly with modern history since the Renaissance, but rather with the Socratic or Alexandrian cultures that have dominated Western history since before the Christian era. 'Modernity' in this sense therefore begins very early indeed." Douglas Burnham and Martin Jesinghausen, Nietzsche's The Birth of Tragedy: A Reader's Guide (London: Continuum, 2010), 117.

${ }^{66}$ Menke, "Critical Theory and Tragic Knowledge," 59.

${ }^{67}$ Gourgouris, Does Literature Think?, 2.

${ }^{68}$ See Adorno, Minima Moralia, 39.

${ }^{69}$ David Hawkes, Ideology (London: Routledge, 2003), 130.

${ }^{70}$ Freyenhagen, Adorno's Practical Philosophy, n. 23.

${ }^{71}$ Cf. Adorno, Negative Dialectics, 3-4.

${ }^{72}$ It should be noted that Adorno's idea of autonomous and heteronomous art is reminiscent of Nietzsche's distinction between the Dionysian and the Apollonian. See Paul Raimond Daniels, Nietzsche and The Birth of Tragedy (London: Routledge, 2013), 41-71.

${ }^{73}$ See Stone, "Adorno, Hegel, and Dialectic."

${ }^{74}$ Cf. Freyenhagen, Adorno's Practical Philosophy.

75 Theodor W. Adorno, History and Freedom: Lectures 1964-1965, ed. Rolf Tiedemann, trans. Rodney Livingstone (Cambridge: Polity Press, 2006), e-book, lecture 25. 
${ }^{76}$ Adorno, History and Freedom, lecture 25: “And the Prince's action at this point seems to be unconnected with the complex, elaborate and rational reflections that have preoccupied him throughout the drama hitherto."

${ }^{77}$ Adorno, History and Freedom, lecture 25.

${ }^{78}$ Ross Wilson, Theodor Adorno (London: Routledge, 2007), 1.

${ }^{79}$ Adorno, Negative Dialectics, 365.

${ }^{80}$ See Gandesha, "Enlightenment as Tragedy."

${ }^{81}$ Gritzner has argued that Adorno's negative dialectical method functions in a way reminiscent of tragedy. Adorno seeks to reveal "the enigmatic and incommensurable substance of human existence" expressed by tragedy: "Tragedy brings about a suspension of the rational principle and there lies its paradoxical power to negate, whilst revealing, the instrumental rationalization of the world." Gritzner, Adorno and Modern Theatre, 170.

${ }^{82}$ The point is obviously not to deny the singularity of Auschwitz. On Adorno's synecdochic usage of “Auschwitz," see Mark J. Webber, "Metaphorizing the Holocaust: The Ethics of Comparison,” Images 8.15-16 (2011): 17-19.

${ }^{83}$ Gritzner, Adorno and Modern Theatre, 167.

${ }^{84}$ See Young, The Philosophy of Tragedy, 8-10.

${ }^{85}$ Gloria Fisk has suggested that the renewed interest in tragedy in the twenty-first century is due to the resemblance between our precarious political situation and that of the Greeks: "And it makes sense that tragedy works during the periods before and after modernity because our age resembles the ancients' to the degree that the limits of our political communities are in flux. Just as the Greeks who sat in tragedy's theaters tried to imagine that they belonged to the newly formed polis, the constituents of the 'global community' try to imagine that they belong to each other in some meaningful way." Fisk, "Putting Tragedy to Work for the Polis," 895.

${ }^{86}$ See Gandesha, "The Theatre of the 'Other'." 
${ }^{87}$ In comparing influential views of tragedy and its fate in modernity, Terry Eagleton notes the difficulty of pinning down Adorno's position: “Theodor Adorno's tone about tragedy is rather more ambiguous [than Lukács's, Hegel's, or George Steiner's]: the form has died, so we are informed, because 'nobility' has fallen victim to cultural 'vulgarity'. Yet Adorno, in typically dialectical style, also insists that though nobility in art must be preserved, its collusion with social privilege and political conservatism must be exposed." Terry Eagleton, Sweet Violence: The Idea of the Tragic (Malden, MA: Blackwell, 2003), 87. Adorno's ambiguous view on nobility and vulgarity referred to by Eagleton is discussed in the "Paralipomena" section of the Aesthetic Theory, esp., 313-15. ${ }^{88}$ It is unclear whether Adorno's reservation, which “may have been the origin of the idea of aesthetic autonomy," is due to his reluctance to make a bold historical claim or his suspicion of tragedy as such. He definitely agrees that there is a connection between the social role of tragedy and the autonomy of art: "Unquestionably, Attic tragedy was also the crystallization of no less a universal than the reconciliation of myth. Great autonomous art originated in agreement with the emancipation of spirit; it could no more be conceived without an element of universality than could the latter." Adorno, Aesthetic Theory, 6-7, 200.

${ }^{89}$ Hence the idea of tragedy as "an afterimage of cultic acts," just as modern artworks are “afterimages of empirical life.” Adorno, Aesthetic Theory, 6, 4.

${ }^{90}$ Adorno mentions tragedy as an example of an art that has mistakenly been believed to have permanent value. See Adorno, Aesthetic Theory, 28. For Adorno, modernism has shown that artistic forms are born out of a battle between tradition and innovation. On this, see David Cunningham, "A Time for Dissonance and Noise: On Adorno, Music, and the Concept of Modernism," Angelaki, 8.1 (2003): 61-74. Also, George Steiner's influential analysis of the death of tragedy makes a similar point by arguing that the Greek world-view is incompatible with the Judeo-Christian one. See Steiner, The Death of Tragedy. Cf. Walter Kaufmann, Tragedy and Philosophy (Princeton, NJ: Princeton University Press, 1992), 317-22. 
${ }^{91}$ Adorno writes dismissively of such socially conscious art in his famous essay "Commitment," in Notes to Literature, vol. 2, 77-94.

${ }^{92}$ Artworks can be critical only insofar as they communicate the truth, but the truth is not dependent on the form. Yet there is no form that is critical in itself. The dialectic of form and content produce the artwork within a historical context. "The truth content of artworks is fused with their critical content." Adorno, Aesthetic Theory, 35.

${ }^{93}$ To put it in Adornian terms, without reifying and commodifying them.

94 "In this regard, the category of tragedy should be considered. It seems to be the aesthetic imprint of evil and death and as enduring as they are. Nevertheless it is no longer possible." Adorno, Aesthetic Theory, 28.

${ }^{95}$ The first substantial philosophical enquiry into the tragic as something separate from the tragedies themselves is generally believed to have been made by Schelling. As Peter Szondi opens his oftquoted book on the topic: "Since Aristotle, there has been a poetics of tragedy. Only since Schelling has there been a philosophy of the tragic.” Peter Szondi, An Essay on the Tragic, trans. Paul Fleming (Stanford, CA: Stanford University Press, 2002), 1.

${ }^{96}$ The distinction between necessary and unnecessary suffering is a complex but important one. To crudely summarize, the proponents of the tragic view tend to hold that the Greeks saw human suffering as inevitable and meaningless, while the Christians saw it as likely but meaningful. See, for example Steiner, Death of Tragedy, chap. 1. Philosophers, such as Schopenhauer and Nietzsche, sought to forge some sort of an amalgam of these positions with Schopenhauer deeming inevitable suffering as the meaning of life. Nietzsche considered suffering in a godless world as essentially meaningless but something that can be overcome. Adorno, for his part, seems to think that some forms of suffering are inevitable (some of us fall ill and we all die), while others are not (poverty, wars, societal ills in general), and that the tragic view should only pertain to the latter kind: suffering that could be avoided is meaningless and it is the duty of art and philosophy to remind us of that. On Schopenhauer and Nietzsche on tragedy, see Bowie, German Philosophy, 70-75. 
${ }^{97}$ Adorno, Aesthetic Theory, 28.

${ }^{98}$ Terry Eagleton writes that Adorno was suspicious of tragedy because it was at constant risk of making suffering appear as meaningful: "It seemed to him to impose too much sense on the senseless, and thus to diminish its horror. The very form of the art risks making its sordid content more palatable and coherent than it is." Terry Eagleton, Culture and the Death of God (New Haven, CT: Yale University Press, 2014), 172.

${ }^{99}$ As Gritzner puts it, they "are designed to obscure and conceal contradictions and conflict on the level of culture," providing us with "a false mimesis of the social reality which gives rise to them." Gritzner, Adorno and Modern Theatre, 167.

${ }^{100}$ Among modern commenters, this understanding of the tragic view of life seems more common than the one which assumes the hidden workings of the gods to provide life with reason and meaning. As George Steiner writes: “Euripides' Bacchae stands in some special proximity to the ancient, no longer discernible spring of tragic feeling. At the end of the play, Dionysus condemns Cadmus, his royal house, and the entire city of Thebes to a savage doom. Cadmus protests: the sentence is far too harsh. It is utterly out of proportion with the guilt of those who fail to recognize or have insulted the god. Dionysus evades the question. He repeats petulantly that he has been greatly affronted; then he asserts that the doom of Thebes was predestined. There is no use asking for rational explanation or mercy. Things are as they are, unrelenting and absurd." Steiner, Death of Tragedy, 9 .

${ }^{101}$ Suffering, Adorno argues, "demands the continued existence of the very art it forbids; hardly anywhere else does suffering still find its own voice, a consolation that does not immediately betray it." The risk of betrayal is, however, an essential part of even the most thoughtful and sensitive art: "The so-called artistic rendering of the naked physical pain of those who were beaten down with rifle butts contains, however distantly, the possibility that pleasure can be squeezed from it.” Adorno, Notes to Literature, vol. 2, 88. 
${ }^{102}$ One reason for Adorno's philosophical negativity is his reluctance to affirm the nihilism of the regressive capitalist culture. Yet the negation of this nihilism does not mean the assertion of positivity. See Gandesha, "The Theatre of the 'Other'." 